By ROBERT E. DYSINGER

\title{
The Research Library in the Undergraduate College
}

$I^{N}$ N THE PAST, librarians have written well in pointing out the need for extreme selectivity in the acquisition of books for a college library. Thinking of such a library primarily as an undergraduate, students' library, it has been said that such a library need have a collection, actively weeded, of only 100,000 volumes. Indeed, some librarians, basing their conclusions on the original 1931 Shaw List, felt that a collection of far less than 100,000 volumes might well fill the needs of the undergraduate institution.

This writer can no longer agree with such a philosophy. The usual excuse given for a small college's existence is that it is able to give a more intensive, individualized education than the university. Today the small college is in a critical period as more and more young people do undergraduate work, institutions become rapidly larger, and teaching faculty members are more in demand. This demand today is creating for the small college an ever increasing problem-that of keeping teaching scholars-and such scholars cannot be kept by salary alone. High in the heirarchy of reasons valuable professors stay in a particular college or university is good research facilities.

A faculty member today, in a time of rapid advancement of knowledge, must work hard to keep himself acquainted with new developments in his field. The

Mr. Dysinger is Assistant Librarian, Bowdoin College. literature of science and the social sciences is enormous and is still growing. Writing in the fields of fiction, poetry, and drama in all languages approaches a flood. Obviously the faculty members in the small college should be those best able to present our complex, modern world to students. Often enough the teachers best able to do this are themselves deeply involved in contributing to and in organizing knowledge.

Furthermore, administrations in colleges today are strongly urging teaching faculty members to publish. Faculty men and women, trying to keep abreast of their subjects and contribute to them, and faced with the countless distractions of college and community life today, are best satisfied when the materials for their work are easily available. As a means for keeping good people in our small colleges, books for scholars should be close at hand.

This problem of having research material at hand is far greater in the more sparsely populated sections of the country. A college library need not buy the Monumenta Germaniae Historica if the next town is Cambridge or New Haven, but if the library is located, as many are, one or two hundred miles from a large center, the situation is altered. In the hinterland of our nation, college libraries today will need to have much more than undergraduate collections. If we must put a figure on it, a collection which reflects the curriculum of the institution and the interests of individual scholars and is well selected and thinned 
will bulk large and have far in excess of 250,000 volumes.

It is obvious that centralized buying and storage libraries, for those who have them, and the interlibrary loan program both help keep college libraries in business today, but such aids are not enough. It is certain that small colleges will have to shoulder the burden themselves, individually, of having at least beginning research facilities readily available on their own campuses, or face losing many of the best scholars and students to the large universities.

Such comments from faculty members as: "We need very many government documents," from an economist, or, "I need most foreign journals in biology," from a biologist, or, "Bibliographies of manuscript sources have proven helpful," from an American history professor, suggest the special problems of research needs today. One historian notes eleven bibliographical works in the field of French history, starting with the Briere and Caron, Repertoire methodique de l'Histoire moderne et contemporaine de la France, all of which he feels are necessary to his work.

An English professor feels we should buy very heavily in the field of the English novel since World War II. An ornithologist needs complete, indexed files of The Ibis, The Auk, The Wilson Bulletin, The Condor, and the Journal für Ornithologie, and says that, in addition to the standard journals in more or less "pure" zoology and botany, he needs as badly Ecology, Ecological Monographs, The Journal of Ecology, The Journal of Animal Ecology, Behavior, Evolution, The American Midland Naturalist, and many others. He also says that in regard to his interest in biological history he needs Thwaites' Jesuit Relations and Early Western Travels, McKelvey's Botanical Exploration of the Trans-Mississippi West, 1790-1850, and "indeed, anything in the field of travel may be of interest." A member of the French department, working in philology, French literature of the sixteenth century, and with medieval French texts, has wide interests and needs in these fields. Little of this material will be used by undergraduates. A man in the department of government often uses the English Hansard's, and has asked us to buy the complete publications of the United $\mathrm{Na}$ tions. These examples indicate something of the variety and rarity of library requests today in a small undergraduate college. Requests for research materials are ever larger in number.

Faculty members seriously dedicated to adding to the sum of man's knowledge, and to providing an intense and individualized education for their students, are justified in requesting their college library to buy little-used materials that are important to their work as both teachers and scholars. To satisfy such requests, libraries need proper budgets, both for books and for trained personnel.

An educational program for administrators, governing boards, and alumni of colleges as to the primacy of large budgets for libraries today needs to be constantly underway. We can only hope that through such education money for faculty research materials can be partially supplied. If it is not the small liberal arts college will find it difficult to attract and hold good scholars and secure good students, and as an educational institution it may cease to be very important.

Chaucer describes his "Clerc" as a man who,

"Yet hadde he but litel gold in Cofre

But al that he myghte of his frendes hente

On bookes and on lernynge he it spente...."

How could we have better advice on what to do with our money in days like these? 